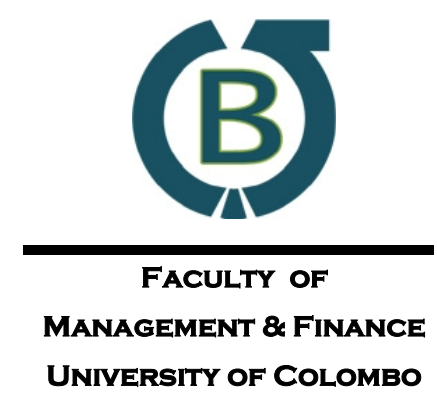

UNIVERSITY OF COLOMBO
Vol. 07, No. 01, June, 2016
Colombo

Business

Journal

International Journal

of Theory \& Practice

\title{
Institutionalization of Activity Based Costing in a Sri Lankan Manufacturing Firm: A Case Study
}

\author{
S. Cardes ${ }^{a}$, Tharusha N. Gooneratne ${ }^{1 b}$ \\ ${ }^{a} B B A$ Programme, Department of Accounting, University of Colombo, Sri Lanka \\ ${ }^{b}$ Department of Accounting, University of Colombo, Sri Lanka
}

\begin{abstract}
The aim of this paper is to identify the reasons for the implementation and subsequent institutionalization of activity based costing (ABC) in a manufacturing subsidiary of a large local conglomerate, Sigma and the uses of $\mathrm{ABC}$ information by various managers. The paper adopts the qualitative case study approach and leans on the theoretical lens of old institutional economics (OIE). Our findings reveal that the implementation of $\mathrm{ABC}$ in Sigma was driven by the parent company's decision to implement SAP (for the group) as the enterprise resource planning (ERP) system of which $\mathrm{ABC}$ was embedded as the accounting module. $\mathrm{ABC}$ has been in use for over ten years in Sigma, and it has become an institutionalized practice. The institutionalization of ABC in Sigma characterizes both ceremonial as well as instrumental institutionalization, and show that ceremonial institutionalization can be made effective if it can be successfully embedded to the operations of the firm, through instrumental institutionalization. This is a useful theoretical contribution of this research. This study is also an important addition to existing management accounting literature in the area of $\mathrm{ABC}$, and its findings offer valuable insights to practicing managers on the implementation and use of $\mathrm{ABC}$.
\end{abstract}

Keywords: Activity Based Costing, Institutionalization, Ceremonial Institutionalization, Instrumental Institutionalization, Case Study

\section{Introduction}

The contemporary business environment features advances in technology, changing operational processes and globalization pressures, which have led both practitioners and academics to question the suitability of information generated through traditional management accounting systems (Joshi, 2001). Innovative strategic management accounting techniques have thus been introduced by business consultants and scholars to provide managers with appropriate information for decision making. Activity based costing ( $\mathrm{ABC}$ ) is one such technique which has advantages over traditional accounting systems (Bjornenak, 1997).

${ }^{1}$ Corresponding Author: tharushng@dac.cmb.ac.lk 
There is a widespread interest on $\mathrm{ABC}$ in the literature, with a lot of journal space and conference time being devoted to it (Clarke, Hill, \& Stevens, 1999). It has also been diffused to different parts of the world (Bjornenak, 1997; Joshi, 2001; Nassar, Aldeen Al-Khadash, \& Sangster, 2011). ABC is claimed to provide more accurate and relevant product cost information for managerial decision making compared to traditional costing systems by making managers aware of the cost drivers which cause costs (Clarke et al., 1999; Innes \& Mitchell, 1997). This is especially suitable in a context of complex manufacturing processes with a wide range of products and declining direct labour input (Bhimani \& Pigott, 1992). Despite its theoretical merits, some ABC implementations have failed or have been partially implemented, and prior literature shows that $\mathrm{ABC}$ systems end up in differerent fates in different organizational contexts in terms of success, failure, continuation and discontinuation (Bhimani \& Pigott, 1992; Clarke et al., 1999; Joshi, 2001; Major \& Hopper, 2005; Malmi, 1997; Norris, 2002; Soin, Seal, \& Cullen, 2002). Although important from a research and practicing managers point of view, little is currently known on how and why some $\mathrm{ABC}$ systems are sustained and institutionalized in organizations, hence, the focus of this paper. We draw field study evidence from a manufacturing subsidiary of a large local conglomerate, Sigma, which has been continuing with $\mathrm{ABC}$ for over ten years. The research questions of this study are; why has the case organization implemented $\mathrm{ABC}$; how is $\mathrm{ABC}$ information used by various managers; how has $\mathrm{ABC}$ been institutionalized as a useful organizational practice?

Although a single site study does not provide conclusive evidence (see Major \& Hopper, 2005), findings of such a study would be a learning point to practicing managers in other manufacturing firms in Sri Lanka as well as in other parts of the world on sustaining new management accounting practices such as $\mathrm{ABC}$ in organizations. From a theoretical point of view, this paper would be a useful addition to the current body of management accounting knowledge, by providing evidence on institutionalization of $\mathrm{ABC}$, which to date has received limited attention from researchers. Institutionalization of $\mathrm{ABC}$ in Sigma characterizes both ceremonial as well as instrumental institutionalization, and this paper is also important as it provides evidence on how ceremonial institutionalization can be made effective if it can be successfully embedded to the operations of the firm through instrumental institutionalization.

The rest of the paper is structured as follows. Section two reviews past literature on $A B C$ and presents the theoretical lens of the study. Section three is on research context and methodology. Findings and a discussion of the findings are offered in section four, while sections five presents the conclusions.

\section{Literature Review and Theoretical Lens}

$\mathrm{ABC}$ has emerged as a means to address the drawbacks of traditional costing systems by providing more accurate product cost information. Past literature has discussed the adoption and diffusion of ABC (Bjornenak, 1997; Joshi, 2001), its benefits, problems, uses and success factors (Bhimani, Gosselin, Ncube, \& Okano, 2007; Byerly, Revell, \& Davis, 2003; Krumwiede, 1998; Shields, 1995), as well as ABC experiences in various countries (Alcouffe, Berland, \& Levant, 2008; Adler, Everett, \& Waldron, 2000; Clarke et al., 1999; Major \& Hopper, 2005; Norris, 2002).

The most common benefit of $\mathrm{ABC}$ is the provision of accurate product and service costing (Byerly et al., 2003; Innes \& Mitchell, 1997; Swenson, 1995). An ABC system would produce useful cost information for companies who produce different ranges of products with differing batch sizes, 
consuming different amounts of resources, using complex manufacturing processes (Bhimani and Pigott, 1992; Clarke et al., 1999; Johnson, 1992). Such organizations can gain strategically relevant information from an $\mathrm{ABC}$ system for sourcing, pricing, product mix, customer profitability and decisions on process improvement, product design and performance management (Clarke et al., 1999; Swenson, 1995) and new product development (Berts \& Kock, 1995). ABC can be viewed differently from the eyes of various managers in different departments of the same firm, and can be used for various purposes. Bhimani and Pigott (1992) note how ABC was perceived to be successful by factory managers and head office managers, while sales personnel were unhappy with it. Swenson (1995) reported where corporate level finance managers were satisfied with $\mathrm{ABC}$ as a cost management system, while non-financial managers were not. In a Portuguese telecommunication firm $\mathrm{ABC}$ proved problematic as the production area managers were not satisfied with it, while commercial managers and senior managers were satisfied as it served their pricing and investment decisions (Major \& Hopper, 2005). Given the benefits of ABC, its difussion also has been a topic of interest among the past researchers. Difusion of ABC studies based in France (Alcouffe et al., 2008), Norway (Bjornenak, 1997) Finnish organizations (Malmi, 1997) and India (Joshi ,2001) are significant in this regard.

Although $\mathrm{ABC}$ offers many benefits, it is not free from problems. Its implementation is expensive and time consuming (Swenson, 1995), and it is difficult to quantify its economic benefits (Clarke et al., 1999). Lack of managerial acceptance of the information generated through $A B C$ (Innes \& Mitchell, 1997), lack of top management support and a group level sponsor has been linked to ABC failure (Clarke et al., 1999; Malmi, 1997; Shields, 1995). Further, keeping cost drivers up to date is problematic as cost driver rates needed to be changed as and when a change in an activity occurred (Soin et al., 2002), and resistence to ABC implemetation could occur due to organizational power and politics, issues on cost and benefits as well as reasons stemming from organizational culture.

While one may argue that $\mathrm{ABC}$ is more visible in the manufacturing sector, currently $\mathrm{ABC}$ has also spread to the service sector. Therefore, a review of past literature reveals that $\mathrm{ABC}$ experiences can be drawn from different countries across various industries in manufacturing and services. In the manufacturing sector, this ranges from a survey study on ABC adoption in Irish manufacturing firms (Clarke et al., 1999), to Krumwiede's (1998) survey on U.S. manufacturing firms on stages of ABC implementation, to a study by Adler et al. (2000) on adoption and utilization of innovative management techniques in New Zealand manufacturing firms, as well as to the study on British phamaceuticals (Bhimani \& Pigott, 1992). In the service sector, several ABC studies are visible in the banking sector. This ranges from the study by Soin et al. (2002) on a clearing department of a U.K. based multinational bank to grounded theory case studies on two British banks (Norris, 2002), and to the survey by Innes and Mitchell (1997) on UK's largest financial institutions. The Portuguese telecommunication case study by Major and Hopper (2005) is also a significant ABC study founded on the service sector. Adding to this literature, the survey study on Australian firms which identifies the determinants of ABC success in mature sites (Byrne, 2011) and the study by Bhimani et al. (2007), which investigates the extent to which organizations have adopted ABC in Canada, France, Germany, Italy, Japan, the U.S. and the U.K are noteworthy.

Literature, however, notes that there are significant differences in the implementation rates across different countries (Bhimani et al., 2007), and due to contextual differences, findings on ABC derived from other countries cannot be taken as given for Sri Lankan organizations. Hence, this paper reports 
on a $\mathrm{ABC}$ story drawn from a Sri Lankan manufacturing organization, in which $\mathrm{ABC}$ has been institutionalized as a useful accounting practice. Institutionalization of $\mathrm{ABC}$ as well as $\mathrm{ABC}$ experiences in Sri Lankan firms has not been the focus in past research. This study therefore fills a gap in research by (a) exploring how $\mathrm{ABC}$ has been institutionalized as a useful accounting practice, and (b) drawing evidence from a Sri Lankan organization (which operate in a different context to those firms focused in past $\mathrm{ABC}$ studies).

\subsection{Theoretical Lens}

As the initial interviews conducted found that $\mathrm{ABC}$ has been continued and institutionalized in the case organization, data was analyzed in light of old institutional economics (OIE), a branch of institutional theory (Burns \& Scapens, 2000; Guerreiro, Pereira, \& Frezatti, 2006; Ribeiro \& Scapens, 2006; Siti-Nabiha \& Scapens, 2005). OIE lays focus on institutions, habits, organizational routines and their institutionalization (Burns \& Scapens, 2000; Ribeiro \& Scapens, 2006). According to Burns and Scapens (2000), when habits and routines are repeatedly reproduced over time they get institutionalized as taken for granted practices. Routines play an important role in the relationship between actions and institutions. Guerreiro et al. (2006) note that routines should be widely accepted in the organization for them to become institutionalized. When institutionalized, they become unquestioned ways of doing things. However, the degree of acceptance of new routines vary according to the different groups within the organization (Guerreiro et al., 2006).

This institutionalization is applicable for management accounting practices and OIE perceives management accounting as routines comprised of established habits which are widely taken for granted (Guerreiro et al., 2006). Accounting practices can turn into routines, when over time they become embedded into the organization's beliefs, and finally people accept them without questioning (Burns \& Scapens, 2000). Such practices then become taken for granted by being recurrently enacted across time and space (Ribeiro \& Scapens, 2006). However, newly introduced management accounting practices which challenge the prevailing institutions of the organization, do not get institutionalized (Burns \& Scapens, 2000). Such institutions may be either resisted or translated into practices to be consistent with existing institutions (Siti-Nabiha \& Scapens, 2005).

Burns and Scapens (2000) state that routines can be institutionalized in two ways; ceremonially or instrumentally. Ceremonial institutionalization occurs to preserve the current status of the organization, and to protect the power and interests of specific groups or individuals. Instrumental institutionalization of routines are used as aid to decision making in organizations. Siti-Nabiha and Scapens (2005) provide an example of an accounting change which was institutionalized in a ceremonial manner. The degree of institutionalization varies based on different groups within the organization, as became evident from the study of Guerreiro et al. (2006) founded upon a Brazilian bank.

The case organization of this study has been using $\mathrm{ABC}$ for over ten years, and this study explores on how and why $\mathrm{ABC}$ has become an institutionalized practice in the firm. Ribeiro and Scapens (2006) state that institutionalization of management accounting practices is a productive area of research. In understanding the continuation of a managment practice, concepts linked to OIE such as routines, taken for grantedness, ceremonial use, decision making use are important. Therefore in exploring the institutionalization of ABC in Sigma PLC, OIE was deemed to be the most suitable. Seeing from OIE perspective, institutionalization of $\mathrm{ABC}$ in the case organization shows evidence of 
ceremonial institutionalization as well as instrumental institutionalization hence, OIE and particularly its core concepts such as routines, taken for granted practices, ceremonial use, instrumental use was used in analysing the findings of this study.

\section{Research Context and Methodology}

The research site of this study is a wholly-owned subsidiary of a leading local conglomerate, which has stakes in transportation, leisure, property, consumer foods and retail, financial services, and information technology (IT) services. In 2004, the group as a whole moved to Standard Application Procedures (SAP), under which the manufacturing companies in the group (including the research site of this study), took $\mathrm{ABC}$ on board as their product costing system. The research site of the current study, referred to as Sigma PLC for confidentiality reasons, is engaged in the manufacturing of soft drinks and ice cream. It operates amid local and international competitors and successfully competes in the market.

This study adopts the qualitative methodology and single case study approach as the research strategy (Silverman, 2000; Yin, 2003), as it appeared to be the most appropriate in addressing research questions of the study, which require understanding of social phenomena and their contexts, i.e. how and why ABC has been institutionalized in Sigma PLC. Data collection has been carried out using multiple methods such as through conducting in-depth interviews, review of internal and external documents and observations of practices (data triangulation). Utilizing different data collection methods in this manner has the advantage of making the research findings more valid, reliable and compelling (Irvine \& Gaffikin, 2006; McKinnon, 1988).

Initially the published documents of the research site was referred and its website was browsed to obtain a background understanding on its business, range of products, profit, turnover and the nature of the competition faced in the market. Thereafter interviews were conducted with the head of management accounting at the head office to obtain a general understanding about $\mathrm{ABC}$ and other management control systems of the organization. It was understood that $\mathrm{ABC}$ plays a prominent role in product costing at Sigma PLC over other management control systems given that it is a manufacturing firm. Hence, ABC system was studied in-depth. With the help of head of management accounting, contacts were established with other informants to collect data.

Two initial interviews were conducted with the head of management accounting during July 2014 and the finance manager of Sigma. ${ }^{1}$ Through these interviews it was evident that $\mathrm{ABC}$ has been in use in the firm for over ten years, and that it has become an established practice. Hence the focus of the study was geared towards exploring the reasons behind the institutionalization of $\mathrm{ABC}$.

Subsequent to these two pilot interviews, the main data collection was commenced in September 2014. A total of ten in-depth interviews were conducted with managers of various hierarchical levels including top managers, finance managers and non-finance managers. The members of the group management committee (GMC) were also interviewed since they were the top most people of the organization involved in strategic decisions on products, pricing etc. Members of the GMC also

\footnotetext{
${ }^{1}$ The interviews suggested that while the head of management accounting was directly involved in ABC related activities, the finance manager was not directly involved in $\mathrm{ABC}$, instead was overall responsible for accounting and finance activities of the firm.
} 
provided useful information regarding $\mathrm{ABC}$ implementation at Sigma. This information was useful as there was no opportunity to conduct interviews with any member of the $\mathrm{ABC}$ implementation team since they were not in employment at Sigma PLC at the time of data collection. According to McKinnon (1988), careful selection of interviewees is important in qualitative field studies.Thus interviewees were selected by looking at the organizational chart, based on who would be in the best position to provide useful insights for the study. Table 1 presents the details on interviewees.

Table 1: Interviewee Details

\begin{tabular}{ll}
\hline Designation of the interviewee & Duration of the interview \\
\hline HR Manager & Twenty minutes \\
President/ Chief Executive Officer (Member of the (GMC) & Thirty minutes \\
$\begin{array}{l}\text { Head - Management Accounting, Consumer Foods Sector, } \\
\text { AVP (Member of the GMC) }\end{array}$ & One and half hours \\
$\begin{array}{l}\text { Finance Manager } \\
\text { Management Accountant (newly recruited) }\end{array}$ & Twenty minutes \\
$\begin{array}{l}\text { Management Accountant } \\
\text { Production Manager- Soft Drinks Category }\end{array}$ & Fifteen minutes \\
$\begin{array}{l}\text { Production Consultant- Ice Cream Category } \\
\text { AVP- Head of Sales \& Marketing- (Ice Cream Category } \\
\text { (Member of the GMC) }\end{array}$ & Fifty minutes \\
$\begin{array}{l}\text { AVP Head of Marketing - Soft Drinks Category (Member of } \\
\text { the GMC) }\end{array}$ & Twenty minutes \\
\hline
\end{tabular}

The interviews were voice recorded, with the permission of the interviewees and transcribed thereafter. Sigma does not keep any manual documents relating to calculation of product cost and all their calculations are fully automated. Therefore, the calculations and details regarding their cost pools which had been fed into the computerized system were observed.

All the field notes, transcripts of interviews and documentary evidence were carefully analyzed to understand how institutionalization of $\mathrm{ABC}$ in the case study firm took place. Through this comprehensive review some important themes were identified. Then these themes were further drilled down to categories to facilitate the analysis process (Irvine \& Gaffikin, 2006). Then the broad themes and categories were related to the key theoretical concepts of OIE and field data was organized around those key themes / theoretical concepts.

\section{Findings and Discussion}

The findings of this study are presented in terms of the implementation of $\mathrm{ABC}$ and its, ceremonial as well as the instrumental institutionalization.

\subsection{Implementation of $A B C$ and Ceremonial Institutionalization}

Sigma implemented ABC in 2004 as its parent company embraced SAP as the enterprise resource planning (ERP) system for the group. With this decision, the subsidiaries of the parent company were compelled to move towards SAP, of which $\mathrm{ABC}$ was embedded as the product costing module. The 
parent company of Sigma has spent a large sum of money on the SAP system, and along with the vendor of the system ensured a match between the ERP system and the nature of the business when it was configured to the companies in the group. One of the management accountants commented:

The company which sold the SAP application looked at the nature of the business when they configured the ERP system and its modules. ABC was suitable to us. That is why the package we have already bought has $A B C$, even though there are other product costing methods. Both the manufacturing companies under our parent company are using ABC as their product costing system in SAP.

$\mathrm{ABC}$ is embedded to SAP as a parent company initiative, and this is a powerful reason behind its institutionalization. One management accountant commented:

SAP facilitates us to use only ABC. We have to go with the ERP system, which our parent company wants. The ERP system does not facilitate us to use any other system. If we want another system to absorb overheads then we have to buy it separately. If so, for costing we have to pay them separately and buy another module. It is going to be a big cost.

Head of management accounting pointed out "we have a SAP based ABC system. It is an established practice here". One management accountant noted that Sigma does not have plans of moving towards another system since their parent company had spent millions of rupees on the installation of SAP. He further added that even if they wanted to move towards another system they could not do it independently without the permission of their parent company as all these investments have been done by the parent company. Further if Sigma is to change its costing system it would have to spend a lot of money to buy a new costing system separately.

The parent company does not have an intention of abandoning SAP. As a consequence it does not wish to abandon $\mathrm{ABC}$ which is embedded into SAP. A member of the top management commented: SAP is a comprehensive system. We use almost all the modules of SAP. We believe in SAP. We have invested a lot in SAP as well as in training people on it. So there is an attachment to SAP and its modules like $A B C$.

In line with these interview comments, given that it has been a parent company initiative, for ten years Sigma has continuously used $\mathrm{ABC}$, and it has become an established practice in the firm. This resembles ceremonial institutionalization.

\subsection{Implementation of $A B C$ and Instrumental Institutionalization}

Apart from the above, the information generated by the $\mathrm{ABC}$ system has been useful to managers of various functional areas who expressed their satisfaction with the technique given its uses for product costing, pricing and other decision making needs of the top management. This leads to instrumental institutionalization of $\mathrm{ABC}$.

\section{Uses of ABC Information for Product Costing}

$\mathrm{ABC}$ is claimed to be more suitable for manufacturing firms with higher levels of design costs, complex manufacturing processes, wide range of products, declining direct labour input (Bhimani \& Pigott, 1992; Krumwiede, 1998), as well as for firms which produce in different batch sizes (Bhimani \& Pigott, 1992; Clarke et al., 1999; Johnson, 1992). Sigma displays such characteristics, such as complex manufacturing operations, a wide range of soft drinks and ice creams, different product sizes in soft drinks $(400 \mathrm{ml}, 11)$ as well as in ice creams $(11,21,41)$, and the firm functions within a machine 
oriented production system. Accordingly, product costing plays a major role, for which the firm has adopted ABC. This shows the suitability of ABC to Sigma's operations.

One management accountant further explained the usefulness of $\mathrm{ABC}$ in terms of absorbing overheads of a particular month to individual products, as it would have many impacts on different areas like profitability. He further commented:

If we are launching a new product we have to come up with the profitability. If it is an investment, we have to do an investment appraisal to see whether it is profitable or not. So, in order to show accurate profitability $A B C$ is useful. In addition, on a monthly basis we are looking at the product wise profitability in each and every channel (general trade, supermarket and spot channel). We are going into detail and calculating the profitability of each product in each channel. For that again we need $A B C$. When arriving at the profitability main two components are material cost and overheads. Based on the recipe the system calculates material cost per unit. In order to absorb overheads to individual products we use $A B C$.

The head of management accounting also pointed out the importance of properly costing individual products separately by drawing the example of plastic and glass bottles. He explained that since the cost structure of a product is somewhat confidential as it comes with the recipe, it is not revealed to everyone. However, since finance manager needs information regarding the cost structure of a product, the finance manager is given such information which is generated through $\mathrm{ABC}$ for the purpose of preparing final financial accounts. He further commented:

If the price of an ingredient increases (e.g. sugar) it will affect the cost of our products and finance people are aware of that.

Accordingly, the main use of Sigma's ABC system is the provision of accurate product costs for individual products which consume different amounts of resources and calculation of individual profitability in each channel. This is alongside the findings of Byerly et al. (2003), Innes and Mitchell (1997) as well as Johnson (1992).

\section{Uses of ABC Information by Different Managers}

Literature claims that $\mathrm{ABC}$ information can be used for various purposes by different managers of the same firm (Bhimani \& Pigott, 1992; Malmi, 1997). Findings from Sigma PLC reinforce this. Management accountants use $\mathrm{ABC}$ generated information to calculate individual product cost accurately in each channel and calculating profits. Finance manager also uses such cost information to aid preparation of financial statements. Members of sales and marketing division use $\mathrm{ABC}$ generated information in planning promotions, to make suggestions on cost reductions and increments to ensure that they earn a positive ROI in their sales. For instance, AVP sales and marketing in ice cream category mentioned "when we plan promotions, cost information of individual products is very important because a promotion ultimately must generate a positive return on investment (ROI). So I need to look at the cost of the product and the gross profit".

More importantly, alongside the findings of Clarke et al. (1999), Innes and Mitchell (1997), Johnson (1992) as well as Joshi (2001), top management of Sigma uses ABC generated cost information to monitor cost trends, to decide about cost increases and decreases, decide prices of certain products and to make decisions on process improvements. $\mathrm{ABC}$ information is also used on a monthly basis at GMC level to discuss changes to be done on the inputs, to understand difficulties faced by the factory staff and to identify areas for cost reductions and price increases. 
These interviewees were thus satisfied with $\mathrm{ABC}$ since it served their separate information requirements. However, production staff do not use costing information generated through $A B C$, rather they provide necessary inputs to the management accountants to feed to the system in order to generate individual cost of products through SAP using ABC. For example as one production personnel explained:

Costing is done by finance division. I only know that production cost is automatically calculated through SAP. Production people are not involved in costing. We are only involved in operational things. Information like rated capacity of a particular product, the resource consumption of a particular product etc. is given by us to the people who are involved in costing.

This was confirmed by one of the management accountants saying "production people are aware that management accountants are using ABC". During interviews it was understood that while some managers were well aware of $\mathrm{ABC}$ and its use, some did not have much knowledge on it. For instance, an HR manager commented, "I have heard that there is something called ABC. It has been there for a long time. But HR people are not involved in it".

It was further evident that the level of understanding and the extent of use of $\mathrm{ABC}$ information by different managers were dependent upon their educational background, as regular training programmes had not been conducted. As one management accountants noted "frequent training programmes have not been conducted here". Two of the management accountants in Sigma are management degree holders from Sri Lankan universities with professional management accounting qualifications. The other management accountant who was newly recruited is a management degree holder from a foreign university. All of them have a thorough knowledge of $\mathrm{ABC}$, and directly handle $\mathrm{ABC}$ related tasks. Other interviewees expressed their involvement and knowledge on the technique in different ways. For instance, Assistant Vice President (AVP) of sales and marketing of ice cream category commented:

They have not explained about ABC. I am a qualified accountant. Therefore, through my professional studies I know well about $A B C$.

Even though the finance manager has an educational background in management accounting being a management degree holder from a government university, he did not get directly involved in $\mathrm{ABC}$ as his job scope did not cover it. AVP of marketing as well as the production manager of soft drinks category and the production consultant of ice cream category were not much familiar about the $\mathrm{ABC}$, as their work and educational background was not in the domain of accounting. AVP of soft drinks category mirrored:

I know that they are using $A B C$, and I have no problems with that. However, I do not know about it in detail as marketing is my subject. I have not followed any management accounting course.

More importantly, everyone in Sigma was aware that $\mathrm{ABC}$ was embedded into SAP and that it was used for product costing in the firm.

\section{Product Pricing Decisions: Market versus Cost Considerations}

Use of $\mathrm{ABC}$ information for better pricing decisions has been widely cited in the literature (Clarke et al., 1999; Innes \& Mitchell, 1997; Swenson, 1995). In contrast, Sigma primarily adopts market based pricing, while its premium range products are priced on costs. Interviewees explained 
that even though $\mathrm{ABC}$ cost information is used for product costing purposes, many other factors need to be considered when pricing products. According to one of the management accountants, since Sigma is operating in an oligopoly market, price competition is very high. If there is an increase in prices of products compared to their competitors, they will lose the market. Many interviewees noted that the firm prefers market based pricing over a cost based pricing method. The newly recruited management accountant commented:

We can cut down or increase cost since it is an internal thing but for pricing market based is more appropriate as we have to be comparable to competitors. We have to look at our competitors' prices and try to adjust our cost accordingly.

The same applies for soft drinks pricing too. Unlike for ice cream Sigma has a number of local as well as international competitors in soft drinks industry. AVP marketing in soft drinks category added:

We follow market based pricing since it is the customer preference that matters the most. Cost is an internal thing and there is no point of pricing based on cost if the customer is unwilling to buy our product at that price. Especially in soft drinks industry we have to compete with top international brands. So we have to see how much competitors charge for a similar offering and go in par with our competitors in pricing.

Most interviewees bore the idea that cost and pricing are two different things. For example head of management accounting noted "we have to keep an eye on competitors. There are times where cost has gone up and we have identified that through $\mathrm{ABC}$ but we have not increased prices because our competitor has not done it".

Even though Sigma primarily uses market based pricing method, in some instances the firm uses $\mathrm{ABC}$ information in pricing decisions. A management accountant commented:

In most of the situations prices are set based on the market. In such cases we are using cost of individual products generated through ABC to find profitability of each product. When we are introducing a product which our competitors do not have, we come up with our own price based on cost incurred.

Reinforcing the above idea, a member of the top management of Sigma noted that pricing decisions are a combination of cost as well as market price depending on the circumstances. While market based pricing is used for majority of products, for unique / premium range products cost plus pricing method is used. Thus the method of pricing is dependent upon the price sensitivity/ price elasticity of the products. The finance manager claimed:

If the price is not that elastic we can go for cost plus method ( $A B C$ approach), however, if the product is price sensitive, market based pricing is more appropriate. Soft drinks are price sensitive so, if we increase prices based on our cost, people might move to others, competitors. However, for ice cream people still go with the brand name.

Similarly, AVP, sales and marketing of ice cream category elaborated:

There are certain products that we do not have a competitive edge since any of the ice cream suppliers can provide it. They are generic products and some players offer it at Rs. 10, 20 less than us. For these products we stay on par with everyone else.

One top manager justified market based pricing stating that "even though we do research and introduce products to the market its long term acceptance depends on the customer. It may sound 
good at the research level of the product, but, the acceptance and preference may change due to factors like affordability”. Despite the above, AVP, sales and marketing of ice cream category noted that premium range ice cream is priced based on cost. For example, she claimed that most of the consumers ask for particular mixes of ice cream not by its name, but by their brand name.

Sigma does price increases after discussing with functional managers and the final decision is taken at the GMC level. The head of management accounting commented:

We provide figures on costs to sales and marketing people. They look at the reports generated by management accountants and when we propose price increases they normally give their feedback and sometimes say "shall we keep it for the moment" etc. Even though management accountants propose price increases they need to agree first, for us to make a price increase since the consumers' pulse is known to sales and marketing people.

According to AVP, sales and marketing of ice cream category prices are set at the beginning of the year. She further commented "marketing and sales will recommend the prices. Looking at the bottom lines, market trends and consumer demands, we propose price increases. These initial proposals are made at the beginning of the year. The final decision regarding prices is with the top management. They might either decide not to take the price increases or to go for higher price increases. Prices are set through the system. Once the decision is made it is frozen for the year unless any drastic changes occur in between".

\section{Product Cost Information for Top Management's Decision Making}

It is the role of management accounting team to provide required costing information to the top management monthly to re-evaluate their existing decisions and make new decisions about product costing, pricing, continuing and discontinuing product lines considering profitability. Head of management accounting noted:

Every month we look at product profitability and the trend of product profitability. As the management accounting team we provide required information to the top management to make decisions about pricing. We also take into account competitor prices, their price increases and decreases. Then the top management decides whether to go with the price increase in par with the competitors or to remain at the same price and to increase the volume. Management accountants propose these and the final decision is with GMC.

Sigma has been maintaining its $\mathrm{ABC}$ system up to date to ensure that it provides useful information for top managerial decision making. According to the head of management accounting, they update cost driver rates every year as there are salary increments, changes in energy cost rates etc. Further there may be machinery replacements which have an impact on the depreciation cost, and insurance companies may increase their premiums. In addition over the years, through usage, machine output can also decline. So the ABC system is updated with all such details.

A management accountant further elaborated upon practices adopted to ensure the successful maintenance of the ABC system. He stated "feedback from the production personnel is obtained when cost driver rates are revised annually since operational factors need to be considered when arriving at cost driver rates. Thus head of the management accounting claimed that their ABC system is based on factory level. He described: 
Production people give inputs to maintain ABC. If any process of production gets changed they have to give us that kind of information to adjust the parameters. It is important to feed the management accounting system with accurate information.

A member of the top management pointed out the importance of the accuracy of inputs received by management accountants from production staff in order to take optimum decisions based on $\mathrm{ABC}$. He provided an example:

$A B C$ system may fail if the input is not given properly. We came across one such situation when we introduced a new product back in December 2010 where the initial cost given by the production people to management accountants was not correct. So, we launched the product at RS. 650 to the market and eventually they figured that actual cost was more. Then we decided there was no point of continually producing a product at a loss or at break even and discontinued the product. These kinds of situations do not happen very often but there may be rare cases.

Thus to provide accurate information for decision making, management accountants need the support of the production department regarding the input data received. According to the production consultant, from the recipe the management accountants get to know the ingredients. Then information such as quantity of material required is fed into the system in arriving at the raw material cost. The amount of required labour hours for each machine should also be provided. Likewise management accountants are provided with all the required inputs, including on overheads for the purpose of product costing.

Given the various uses of the $\mathrm{ABC}$ system for product costing, pricing and other top management decision making, Sigma has continued to use $\mathrm{ABC}$, and has no plans to move towards another system in the near future. Almost all interviewees were satisfied with the currently practiced ABC system. One management accountant mentioned "so far we do not have any idea of shifting from $\mathrm{ABC}$ to another" while head of management accounting mentioned in his discussion "ABC is indeed useful". Another management accountant commented, "when we arrive at cost of individual products using $\mathrm{ABC}$ we arrive at a realistic figure rather than other costing methods".

AVP sales and marketing of ice cream category mentioned "I suppose ABC is the best method we can use at the moment. I have not thought of any alternative ways. I am satisfied with the current costing information". She further added:

$A B C$ is very important. Different products consume different amounts of resources. We need to calculate the cost of making that product. For example if I do not know the cost of a particular product I do not know what the cost I have to cover. So, it is important to know the cost. ABC serves that purpose.

AVP marketing of soft drinks category pointed out that Sigma is the market leader for ice cream and the firm could not have come this far if not for the ABC system, which helps them to successfully compete even with international brands in the soft drinks industry. Head of management accounting mirrored:

We have not found a substitute that supersedes $A B C$. The day we find one we might look at pros and cons of going ahead with $A B C$. We have to go with $A B C$ until cons will outweigh pros. At the moment pros of $A B C$ outweigh cons. As for now we are continuing with $A B C$ for the foreseeable future because it is the most suitable method to allocating overheads. 
Literature notes that a major factor for failures in $\mathrm{ABC}$ systems is lack of top management support (Malmi,1997; Shields, 1995). Sigma has been using ABC continuously for ten years and a key reason for its continuous use is the strong support from the top management at the company level and the group level. For instance, a top most manager commented that "at the moment $\mathrm{ABC}$ is the best method of allocating overheads to products, as at now we do not see any better method which can facilitate us in calculating costs of individual products which consume different amounts of resources". It was a group top management's decision to implement SAP; $\mathrm{ABC}$ has been embedded into SAP; hence $\mathrm{ABC}$ gets the same support as SAP from the group management. Sigma does not face any major problems in obtaining the required physical resources, since it was sponsored by their parent company. The firm's management accounting team is also well qualified both academically and professionally, and human resources were not a problem. Sigma does not face difficulties in operating its ABC system as found by Byerly et al. (2003) and Soin et al. (2002), since it maintains a supportive environment with factory staff in obtaining required inputs to the system.

Based on the above analysis, it is apparent that $\mathrm{ABC}$ has become institutionalized in Sigma as a useful organizational practice. It has become a taken for granted system (Burns \& Scapens, 2000); a way of life and part of DNA. Sigma's ABC systems shows ceremonial (as a means to preserve the current status being ingrained with its embedment into SAP), and instrumental (due to uses of the system to various managers) institutionalization.

\section{Conclusion}

Drawing empirical evidence from a manufacturing subsidiary of a large local conglomerate Sigma, this paper explores why organizations implement $\mathrm{ABC}$; how $\mathrm{ABC}$ information is used by various managers; and how and why $\mathrm{ABC}$ has been institutionalized as a useful organizational practice? Our case study data shows that $\mathrm{ABC}$ implementation in the firm was driven by the parent company's decision to embrace SAP as the Enterprise Resource Planning (ERP) package for the group, in which $\mathrm{ABC}$ was embedded as the accounting module. Given the nature of the business and the type of their manufacturing processes, $\mathrm{ABC}$ was the most suitable method to calculate product cost for their premium range. With regard to the uses of $\mathrm{ABC}$ information, it was evident that different managers used it for different purposes. Most of all, across the firm interviewees acknowledged its use.

According to the data gathered, institutionalization of $\mathrm{ABC}$ in Sigma characterizes both ceremonial (parent company initiative) as well as instrumental (uses to various managers) institutionalization. The implementation of $\mathrm{ABC}$ was a 'must to do' being a subsidiary of a large local conglomerate, of which the parent company decided to embrace SAP, of which $\mathrm{ABC}$ was decided and continued as the accounting module. This prevents Sigma from moving towards another system in the near future, and depicts ceremonial institutionalization. Of further importance, Sigma has been using $\mathrm{ABC}$ for over ten years due to user satisfaction. Managers believe $\mathrm{ABC}$ as the most appropriate costing method to the firm and used $\mathrm{ABC}$ information in their decision making process. Interviewees made remarks such as "ABC is the best method that can be used at the moment". This resembles instrumental institutionalization. Seeing in this light, it is evident that even a ceremonial institutionalization can be made effective if it can be successfully embedded to the operations of the firm, through instrumental institutionalization. This is a useful theoretical contribution of the current study. 
Even though there are numerous research studies on $\mathrm{ABC}$ experiences in different countries in the developed world (Bhimani \& Pigott, 1992; Major \& Hopper, 2006; Malmi, 1997; Norris, 2002), there is a scarcity of $\mathrm{ABC}$ research based on developing countries such as Sri Lanka. The findings from the developed countries cannot be simply transferred to the developing world as they are faced with different contextual factors. The current study therefore fills a gap in existing literature on $\mathrm{ABC}$ by providing evidence on instiutionlization of $\mathrm{ABC}$, which to date has received limited attention from researchers. The ABC system of Sigma is essentially a success story, and the findings of the current study offer important insights to practicing managers on the implementation and use of $\mathrm{ABC}$.

This paper suggests several directions for future research. While this study was carried out as a single case study, future researchers are encouraged to incorporate multiple ABC case studies in the same sector or different sectors, and conduct comparative studies in respect of their institutionalization. A further avenue for future research would be to focus on $\mathrm{ABC}$ adoption in the service sector in Sri Lanka to identify the differences in $\mathrm{ABC}$ adoptions between manufacturing and service firms. Future researchers are also encouraged to do such comparisons between ABC experiences in Sri Lanka and in other countries.

\section{References}

Adler, R., Everett, A., \& Waldron, M. (2000). Advanced management accounting techniques in manufacturing: Utilization, benifits, and barriers to implementation. Accounting Forum, 24(2), 131-150.

Alcouffe, S., Berland, N., \& Levant, Y. (2008). Actor-network and the diffusion of management accounting innovations: A comparative study. Management Accounting Research, 19, 1-17.

Berts, K., \& Kock, S. (1995). Implementation considerations for activity-based cost systems in service firms: The unavoidable challenge. Management Decision , 33 (6), 57-63.

Bhimani, A., \& Pigott, D. (1992). Implementing ABC: A case study of organizational and behavioural consequences. Management Accounting Research, 3, 119-132.

Bhimani, A., Gosselin, M., Ncube, M., \& Okano, H. (2007). Activity-based costing: How far have we come internationally? Cost Management , 21(3), 12-17.

Bjornenak, T. (1997). Diffusion and accounting: The case of ABC in Norway. Management Accounting Research, 8, 3-17.

Burns, J., \& Scapens, R. (2000). Conceptualizing management accounting change: An institutional framework. Management Accounting Research, 11, 3-25.

Byerly, D., Revell, E., \& Davis, S. (2003). Benefits of activity- based costing in the financial services industry. Cost Management, 17(6), 25-32.

Byrne, S. (2011). What determines ABC success in mature sites? Journal of Accounting \& Organizational Change, 7(3), 259-277.

Clarke, P., Hill, N., \& Stevens, K. (1999). Activity based costing in Ireland: Barriers to, and opportunities for, change. Critical Perspectives on Accounting, 10, 443-468.

Guerreiro, R., Pereira, C., \& Frezatti, F. (2006). Evaluating management accounting change according to the institutional theory approach. Journal of Accounting \& Organizational Change, 2(3), 196228.

Innes, J., \& Mitchell, F. (1997). The adoption of activity based costing in the United Kingdom's largest financial institutions. The Service Industries Journal, 17(1), 190-203.

Irvine, H., \& Gaffikin, M. (2006). Getting in, getting on and getting out: Reflections on a qualitative research project. Accounting, Auditing \& Accountability Journal, 14(1), 115-145. 
Johnson, H. (1992 September). It's time to stop overselling activity based concepts. Management Accounting , 26-35.

Joshi, P. (2001). The international diffusion of new management acounting practices: The case of India. Journal of International Accounting, Auditing \& Taxation, 10, 85-109.

Krumwiede, K. (1998). The implementation stages of activity-based costing and the impact of contextual and organizational factors. Journal of Management Accounting research, 10, 239-277.

Major, M., \& Hopper, T. (2005). Managers divided: Implementing ABC in a Portuguese telecommunications company. Management Accounting Research, 16, 205-229.

Malmi, T. (1997). Towards explaining activity-based costing failure: Accounting and control in a decentralized organization. Management Accounting Research, 8, 459-480.

McKinnon, J. (1988). Reliability and validity in feild research: Some strategies and tactics. Accounting, Auditing and Accountability, 1(1), 34 - 54.

Nassar, M., Aldeen Al-Khadash, H., \& Sangster, A. (2011). The diffusion of activity-based-costing in Jordanian industrial companies. Qualitative Research in Accounting \& Management, 8(2), 180 200.

Norris, G. (2002). Chalk and cheese: Grounded theory case studies of the introduction and usage of activity-based information in two British banks. British Accounting Review, 34, 223-255.

Ribeiro, J., \& Scapens, R. (2006). Institutional theories in management accounting change. Qualitative Research in Accounting \& Management, 3(2), 94-111.

Shields, M. (1995). An empirical analysis of firm's implementation experiences with activity-based costing. Journal of Management Accounting Research 7, 148-166 .

Silverman, D. (2000). Doing qualitative research. London: Sage Publications.

Siti-Nabiha, A., \& Scapens, R. (2005). Stability and change: An institutionalist study of management accounting change. Accounting, Auditing \& Accountability Journal, 18(1), 44-73.

Soin, K., Seal, W., \& Cullen, J. (2002). ABC and organizational change: An institutional perspective. Management Accouting Research, 13, 249-271.

Swenson, D. (1995). The benefits of activity-based cost management to the manufacturing industry. Journal of Management Accounting Research, 7, 167-174.

Yin, R. (2003). Case study research design and methods. Thousand Oaks, London and New Delhi: Sage Publications. 